\title{
FRACTIONATION OF PROTEIN HORMONES FROM HORSE PITUITARY GLANDS
}

\author{
ANNE STOCKELL HARTREE, JOHN B. MILLS,* \\ ROBERT A. S. WELGH $\dagger$ AND MARJORIE THOMAS \\ Department of Biochemistry, University of Cambridge, and \\ Agricultural Research Council Unit of Reproductive Physiology and Biochemistry, Cambridge
}

(Received 15th November 1967)

\begin{abstract}
Summary. A method developed for separation and partial purification of human pituitary hormones has been applied to acetone-dried horse pituitary glands. Growth hormone, follicle-stimulating hormone and luteinizing hormone activities were each obtained in separate fractions. Further purification of each hormone was achieved by the same or slightly modified procedures effective for the corresponding human hormones and the yields and potencies of the preparations were comparable to those obtained by other investigators. Hormones prepared from acetone-dried horse pituitaries stored for 25 years were of similar yield and potency to those prepared from recently collected glands. Horse and human luteinizing hormones cross-reacted immunologically and the horse hormone was assayed by an immunological method. Strong cross-reactions were observed between horse, pig and beef growth hormones and a very weak cross-reaction between horse and human growth hormones.
\end{abstract}

\section{INTRODUCTION}

A fractionation procedure developed for separation and purification of human pituitary hormones (Hartree, 1966) has been applied to acetone-dried horse pituitary glands. Although these studies have not been so extensive as those with human material, the methods used appear to be applicable, in general, to horse pituitaries. In addition we have had the opportunity to compare hormone activities extracted from acetone-dried horse glands stored for 25 years with glands stored for only a few months. These procedures have resulted in purification of horse pituitary FSH, LH and GH. Methods for purification of these hormones have also been described by Saxena \& Henneman $(1965,1966)$, and Reichert \& Wilhelmi (1965) have prepared horse LH. The hormone activities of our purified fractions appear to be comparable to their preparations on which potency data are available. The successful fractionation of human and horse pituitary hormones by this procedure suggests that it may be of wide applicability.

* Present address: Department of Biochemistry, Emory University, Atlanta, Georgia.

$\dagger$ Present address: Ruakura Agricultural Research Centre, Hamilton, New Zealand. 


\section{MATERIALS AND METHODS}

\section{Source of glands and preparation of pituitary powder}

Horse pituitary glands were collected by Pink Bros., horse slaughterers, in Cambridge. The glands were removed within $10 \mathrm{~min}$ of slaughter, placed in 15 vol. of cold acetone and stored at $4^{\circ} \mathrm{C}$. The first batch of 159 glands (Batch A) was minced in an electric meat grinder (model AC 22; Crypto Ltd, London). The mince was filtered with suction, washed with 5 litres of acetone and spread out in a large tray to dry. The yield of powder was $85 \mathrm{~g}$. A second batch of 160 pituitaries (Batch B) yielded $86.4 \mathrm{~g}$ of powder. An additional batch (No. 22) of horse pituitary glands which were acetone-dried in 1940 as described by Chance, Rowlands \& Young (1939) and stored in an air-tight glass jar at room temperature was kindly provided by Professor A. S. Parkes.

\section{Column chromatography}

The cellulosic ion-exchangers, Whatman CM-70 and Whatman DEAE-50 were treated and equilibrated as described previously (Hartree, 1966). Amberlite IRC-50 (Amberlite CG-50, 200-mesh) was equilibrated as described by Heideman, Bakke \& Lawrence (1959). Whatman DE-32 was precycled and equilibrated by the method recommended by the makers. All column fractionations were carried out at $4^{\circ} \mathrm{C}$.

\section{Extraction of glycoproteins}

The procedure was as described previously (Hartree, 1966). Acetone-dried pituitary powder was extracted twice at $4^{\circ} \mathrm{C}$ with $6 \%(\mathrm{w} / \mathrm{v})$ ammonium acetate, $\mathrm{pH} 5 \cdot 1$, in $40 \%(\mathrm{v} / \mathrm{v})$ ethanol. The soluble extracts were combined and glycoprotein precipitated at $4^{\circ} \mathrm{G}$ by addition of 2 vol. of cold $96 \%(\mathrm{v} / \mathrm{v})$ ethanol slowly with stirring. The mixture was left at $4^{\circ} \mathrm{C}$ for 2 days and the precipitate recovered by centrifugation. After washing once with cold $96 \%(\mathrm{v} / \mathrm{v})$ ethanol and twice with cold ether, it was dried in vacuo. The pituitary residue was washed with cold acetone and air-dried for subsequent extraction of growth hormone (GH).

\section{Preparation of FSH (fraction CP-1) and $L H$ (fraction $C M-2$ )}

All steps were at $4^{\circ} \mathrm{C}$. The glycoprotein precipitate was extracted overnight with $4 \mathrm{~mm}$-ammonium acetate, $\mathrm{pH} 5 \cdot 5$, and centrifuged. The insoluble portion was washed twice with the same buffer and the washings were combined with the original extract. This solution was applied to a column of carboxymethylcellulose (CM-cellulose), previously equilibrated with the same buffer and the column was washed with more buffer until the $E_{280}$ of the effluent decreased to the base line value. The adsorbed fraction was eluted with $\mathrm{M}$-ammonium acetate. The unadsorbed fraction, designated CM-1, was freeze-dried and the adsorbed fraction (CM-2) was adjusted to $\mathrm{pH} 5.5$ with glacial acetic acid and protein precipitated by slow addition of 5 vol. of $96 \%(\mathrm{v} / \mathrm{v})$ ethanol with stirring. After 2 days at $4^{\circ} \mathrm{C}$ the mixture was centrifuged and the precipitate washed and dried as described above. The insoluble portion of the glycoprotein 
precipitate was washed and dried similarly. Fraction CM-1 was further purified by methods described by Butt, Crooke \& Cunningham (1961a) except that calcium phosphate chromatography preceded DEAE-cellulose chromatography as recommended by Dr W. R. Butt (personal communication). Fraction CM-1 $(100 \mathrm{mg}$ ) was dissolved in $10 \mathrm{ml}$ of distilled water and mixed with $10 \mathrm{ml}$ of calcium phosphate suspension in water (prepared according to Main, Wilkins \& Cole, 1959, and containing $10 \mathrm{~m}$-moles calcium). After mixing for $10 \mathrm{~min}$ the suspension was centrifuged and the supernatant fluid added to a suspension of DEAE-cellulose ( $1.5 \mathrm{ml}$ equilibrated DEAE-cellulose plus $8.5 \mathrm{ml}$ buffer) previously equilibrated with $0.01 \mathrm{M}$-ammonium acetate. After mixing for a further $10 \mathrm{~min}$, and centrifugation, the supernatant fluid was treated a second time with the same amount of fresh ion-exchanger. The DEAE-cellulose from both treatments was combined and eluted on a column with $0.2 \mathrm{M}$-ammonium acetate. The effluent (fraction CP-1) was adjusted to $\mathrm{pH} 5.5$ with glacial acetic acid and the protein precipitated with 5 vol. of cold $96 \%(\mathrm{v} / \mathrm{v})$ ethanol, washed and dried as described above.

\section{Preparation of horse growth hormone}

Three methods for preparation of $\mathrm{GH}$ were used. Two were modifications of the method of Raben (1959) in which the hormone is extracted in hot glacial acetic acid, and in the third method extraction was with dilute alkali.

Method 1. The procedure of Raben (1959) was followed (starting with $20 \mathrm{~g}$ acetone-dried pituitary residue after glycoprotein extraction) except for the last step (ethanol precipitation of growth hormone). For further purification a method devised by Chen, Howard \& Wilhelmi (unpublished) and Chen (1964) for purification of pig $\mathrm{GH}$ was employed. The GH-containing solution was adjusted to $\mathrm{pH} 4 \cdot 0$ with $\mathrm{N}-\mathrm{HCl}$ and solid ammonium sulphate added with stirring to a concentration of $1.25 \mathrm{M}$. The mixture was kept at $4^{\circ} \mathrm{C}$ overnight and centrifuged. The precipitate was taken up in $75 \mathrm{ml} \mathrm{H}_{2} \mathrm{O}$ and $10 \mathrm{~N}-\mathrm{KOH}$ was added to the stirred mixture until the $\mathrm{pH}$ rose to 10.5 and a clear solution was obtained. Then $13.0 \mathrm{~g}$ of solid ammonium sulphate was added, to bring the concentration to $1.2 \mathrm{M}$, and the $\mathrm{pH}$ was adjusted to 7.0 . After $18 \mathrm{hr}$ at $4^{\circ} \mathrm{C}$ the mixture was centrifuged, the precipitate taken up in water, dialysed and freeze-dried to yield $296 \mathrm{mg}$ (preparation E $192 \mathrm{~A}$ ). Of this fraction $286 \mathrm{mg}$ was further purified by dissolving it in $\mathrm{H}_{2} \mathrm{O}$, removing precipitates at $\mathrm{pH} 4.9$ (in water) and at $\mathrm{pH} 7.0$ (in $0.25 \mathrm{M}$-ammonium sulphate), and reprecipitating the $\mathrm{GH}$ with $1.2 \mathrm{M}$-ammonium sulphate. The precipitate was taken up in water, dialysed and freeze-dried to yield $68 \mathrm{mg}$ (preparation E $198 \mathrm{C}$ ).

Method 2. The procedure of Raben (1959) was followed omitting the oxycellulose treatments for removal of AGTH.

Method 3. Crude $\mathrm{GH}$ was prepared by suspending $20 \mathrm{~g}$ acetone-dried pituitary residue (after glycoprotein extraction) in $400 \mathrm{ml} 0.1 \mathrm{~N}-\mathrm{NaOH}$ at $4^{\circ} \mathrm{C}$. The mixture was stirred for $15 \mathrm{~min}$, the $\mathrm{pH}$ was adjusted to 10.5 with $4 \mathrm{~N}-\mathrm{HCl}$ and stirring was continued overnight at $4^{\circ} \mathrm{G}$. The $\mathrm{pH}$ was adjusted to $7 \cdot 0$, the mixture centrifuged and the residue re-extracted at $\mathrm{pH} 10.5$ for $1 \mathrm{hr}$. After adjustment to $\mathrm{pH} 7.0$ and centrifugation, the extract was combined with the first extract and $10 \mathrm{~N}-\mathrm{KOH}$ added, with stirring, until the solution was $0.3 \mathrm{M}$ in potassium 
ion. This solution was adjusted to $\mathrm{pH} 8.5$ with glacial acetic acid and centrifuged. The supernatant fluid was treated with an equal volume of $96 \%(\mathrm{v} / \mathrm{v})$ ethanol at $4^{\circ} \mathrm{C}$ with stirring. After centrifugation the precipitate was washed with cold ethanol and acetone and dried in vacuo to yield $6.4 \mathrm{~g}$ of crude $\mathrm{GH}$.

\section{Biological assays}

FSH was assayed in mice by the augmentation assay (Brown, 1955; Butt, Grooke, Cunningham \& Evans, 1961b) which depends on the increase in weight of the ovary of the immature mouse treated simultaneously with the test material and human chorionic gonadotrophin. The precision of the assays was poor initially, but was greatly improved by using litter mates as suggested by Brown \& Wells (1966). Growth hormone was assayed by its effectiveness in increasing the weight of hypophysectomized rats (Hartree, Kovačić \& Thomas, 1965).

\section{Immunological studies}

These were performed by the haemagglutination inhibition method which has been described previously (Hartree, 1966). Antiserum to human GH was prepared as described by Ehrlich \& Randle (1961). Antiserum to human pituitary LH (of potency five times standard NIH-LH-s1) was raised in rabbits using Freund's complete adjuvant. (A horse antiserum to the same LH preparation was prepared by Miss Marion Wood, Wellcome Research Laboratories.) Antiserum to pig $\mathrm{GH}$ (Wilhelmi preparation P 511 A of potency 2.3 i.u./mg) was produced in guinea-pigs by Dr Neil Powers using Freund's complete adjuvant. Immunological estimates for horse LH were performed using sheep red blood cells coated with human chorionic gonadotrophin (of potency 2790 i.u./mg kindly provided by Dr W. J. Tindall of Organon Laboratories) and antiserum to human pituitary LH. The cross-reaction between horse pituitary fractions and antiserum resulted in neutralization of the antiserum and inhibition of haemagglutination. The concentration of horse LH was estimated by the same procedure used for human LH (Hartree, 1966) and the results are expressed on a weight for weight basis as percentage of a human LH standard (of biological potency five times standard NIH-LH-s1). The immunoassay values are not a measure of biological potency since they are based on a relatively weak cross-reaction, but they provide a basis of comparison of $\mathbf{L H}$ content of various horse pituitary fractions.

\section{RESULTS}

\section{Extraction of glycoproteins and separation of FSH from $L H$}

The procedures, which were developed for fractionation of human glycoprotein hormones (Hartree, 1966), are outlined in Scheme 1. The weight yields for each fraction together with biological assays for FSH and immunological estimates for LH are given in Table 1. Although the yield of glycoprotein fraction from acetone-dried powder stored for 25 years (Batch 22) was somewhat 
less than the yield from recently collected pituitaries, the FSH and LH activities in the fractions are comparable. Chromatography on GM-cellulose resulted in concentration of FSH in fraction CM-1 and a second fraction (GM-2) containing LH and low in FSH.



SCHeme 1. Flow sheet for separation of horse pituitary GH, FSH and LH into individual fractions.

TABLE 1

WEIGHT YIELDS AND ASSAYS OF FSH AND LH IN HORSE PITUITARY FRACTIONS

\begin{tabular}{|c|c|c|c|c|}
\hline Fraction & $\begin{array}{l}\text { Yield }(\mathrm{g} / 100 \mathrm{~g} \text { of } \\
\text { pituitary powder })\end{array}$ & $\begin{array}{c}\text { FSH assay with } \\
\text { fducial limits } \\
(\mathrm{P}=0.95)(i . u . / \mathrm{mg})^{\mathbf{a}}\end{array}$ & $\begin{array}{l}\text { Index of } \\
\text { precision } \\
(\lambda)^{*}\end{array}$ & $\begin{array}{c}\text { Immunological } \\
\text { estimate of } \\
\text { LH }(\% \% \text { of } \\
\text { human LH std })\end{array}$ \\
\hline $\begin{array}{l}\text { Acetone-dried powder } \\
\text { (Batch A) }\end{array}$ & 100 & Not assayed & & 0.009 \\
\hline $\begin{array}{l}\text { Glycoprotein ppt. } \\
\text { (from Batch A) }\end{array}$ & 3.55 & $14(5 \cdot 7$ to 33$)$ & 0.5 & $0.37 ; 0.25$ \\
\hline $\begin{array}{l}\text { Acetone-dried powder } \\
\quad \text { (Batch 22) }\end{array}$ & 100 & $0.64(0.44$ to 1.5$)$ & 0.21 & Not assayed \\
\hline $\begin{array}{l}\text { Glycoprotein ppt. } \\
\text { (from Batch 22) }\end{array}$ & $2 \cdot 14$ & $20(14$ to 37$)$ & $0 \cdot 18$ & $0 \cdot 31 ; 0 \cdot 10$ \\
\hline $\begin{array}{l}\text { CM-1 }(28-7-65)^{\mathrm{c}} \\
\text { CM-2 }(28-7-65)^{\mathrm{c}}\end{array}$ & $\begin{array}{l}0.73 \\
0.45\end{array}$ & $\begin{array}{l}35 \\
<10\end{array}$ & $0 \cdot 45$ & $\begin{array}{l}\text { Not assayed } \\
\text { Not assayed }\end{array}$ \\
\hline $\begin{array}{l}\text { CM-1 }(8-11-65)^{\mathbf{d}} \\
\text { CM-2 }(8-11-65)^{\mathbf{d}}\end{array}$ & $\begin{array}{l}1.54 \\
0.93\end{array}$ & $\begin{array}{l}40(14 \text { to } 110) \\
<15\end{array}$ & $0 \cdot 31$ & $\begin{array}{l}0.31 ; 0.09 \\
0.33\end{array}$ \\
\hline CM-1 $(10-1-66)^{e}$ & $1 \cdot 4$ & $23(11$ to 70$)$ & $0 \cdot 22$ & $0 \cdot 12$ \\
\hline
\end{tabular}

$* \lambda=$ The standard deviation/The slope of dose-response curve.

The Second International Standard of Human Menopausal Gonadotrophin was used as standard.

- Rabbit antiserum to human LH was used for all immunoassays.

c Prepared from $135 \mathrm{mg}$ glycoprotein ppt. from Batch A; GM-cellulose column dimensions: $1 \times 30 \mathrm{~cm}$.

d Prepared from $500 \mathrm{mg}$ glycoprotein ppt. from Batch A; CM-cellulose column dimensions: $2 \times 30 \mathrm{~cm}$.

- Prepared from $4.0 \mathrm{~g}$ glycoprotein ppt. from Batch $\mathrm{A}$ and from Batch 22; CM-cellulose dimensions: $5 \times 30 \mathrm{~cm}$. 
Further purification of FSH

Fraction CM-1 was further purified by calcium phosphate adsorption and DEAE-cellulose chromatography as described in the Materials and Methods section. The purified material (CP-1) was partitioned between ethyl cellosolve, salt and urea as described by Butt, Crooke \& Wolf (1965). The yields and

TABLE 2

WEIGHT YIELDS AND ASSAYS OF PURIFIED HORSE FSH PREPARATIONS

\begin{tabular}{|c|c|c|c|}
\hline Preparation & $\begin{array}{l}\text { rield }(\mathrm{g} / \\
100 \mathrm{~g} \text { of } \\
\text { pituitary } \\
\text { powder) }\end{array}$ & $\begin{array}{c}\text { FSH assay with } \\
\text { fiducial limits } \\
(\mathrm{P}=0.95) \\
(\text { i.u. } / m g)^{\mathrm{a}}\end{array}$ & $\begin{array}{l}\text { Index of } \\
\text { precision } \\
(\lambda)\end{array}$ \\
\hline $\begin{array}{l}\text { CP-1 }(17-1-66) \\
\text { CP-1 }(14-4-66) \\
\text { CP-1 }(5-5-66) \\
\text { CP-1 }(10-6-66) \\
\text { Urea/saline/cellosolve }(3-5-66) \\
\text { Urea/saline/cellosolve }(31-5-66)\end{array}$ & $\begin{array}{l}0 \cdot 13 \\
0 \cdot 18 \\
0 \cdot 12 \\
0 \cdot 14 \\
0.063 \\
0.056\end{array}$ & $\begin{array}{l}215(160 \text { to } 320) \\
252(125 \text { to } 590) \\
162(124 \text { to } 257) \\
109(63 \text { to } 237) \\
<100 \\
38(12 \text { to } 150)\end{array}$ & $\begin{array}{l}0.14 \\
0.36 \\
0.06 \\
0.22 \\
0.24\end{array}$ \\
\hline
\end{tabular}

a The Second International Standard of Human Menopausal Gonadotrophin was used as standard.

TABLE 3

WEIGHT YIELDS AND IMMUNOASSAYS OF HORSE LH PREPARATIONS PURIFIED BY CHROMATOGRAPHY ON DEAE-GELLULOSE

\begin{tabular}{|c|c|c|c|}
\hline Fraction & Conditions for elution & $\begin{array}{l}\text { Yield }(g / 100 \mathrm{~g} \text { of } \\
\text { pituitary powder) }\end{array}$ & $\begin{array}{l}\text { Immunological estimates of } \\
L H(\% \text { of human LH std })\end{array}$ \\
\hline $\begin{array}{ll}\text { DEAE-1 } & (16-11-65) \\
\text { DEAE-2 } & (16-11-65)\end{array}$ & $\begin{array}{l}0.1 \mathrm{M} \text {-glycine, } \mathrm{pH} 9.5 \\
1 \mathrm{M} \text {-ammonium acetate }\end{array}$ & $\begin{array}{l}0.051 \\
0.39\end{array}$ & $\begin{array}{l}1 \cdot 8 * \\
0 \cdot 22 *\end{array}$ \\
\hline $\begin{array}{l}\text { DEAE-I } \quad(25-11-65) \\
\text { DEAE-II }(25-11-65)\end{array}$ & $\begin{array}{l}0.25 \mathrm{M} \text {-glycine, } \mathrm{pH} 9.5 \\
1 \mathrm{M} \text {-ammonium acetate }\end{array}$ & $\begin{array}{l}0.26 \\
0 \cdot 32\end{array}$ & $\begin{array}{l}1 \cdot 2^{*} \\
0 \cdot 18^{*}\end{array}$ \\
\hline DEAE-I (19-1-66) & 0.25 m-glycine, $\mathrm{pH} 9.5$ & $0 \cdot 21$ & $\begin{array}{l}3.0^{*} ; 3 \cdot 0 \dagger \\
2 \cdot 5+; 2 \cdot 4 \dagger\end{array}$ \\
\hline DEAE-II (19-1-66) & $1 \mathrm{M}$-ammonium acetate & $0 \cdot 20$ & $0.14 * ; 0.33 \uparrow$ \\
\hline $\begin{array}{l}\text { DEAE-I } \quad(13-9-66) \\
\text { DEAE-II }(13-9-66)\end{array}$ & $\begin{array}{l}0.25 \mathrm{M} \text {-glycine, } \mathrm{pH} 9.5 \\
1 \mathrm{M} \text {-ammonium acetate }\end{array}$ & $\begin{array}{l}0 \cdot 22 \\
0 \cdot 16\end{array}$ & $\begin{array}{l}1 \cdot 1 \dagger ; 1.6 \dagger \\
1.3 \dagger ; 1.2 \dagger\end{array}$ \\
\hline
\end{tabular}

* Assayed using horse antiserum to human LH.

$\dagger$ Assayed using rabbit antiserum to human LH.

potencies of the preparations are given in Table 2. Calcium phosphate adsorption followed by DEAE-cellulose chromatography resulted in a more than five-fold increase in potency over GM-1 and approximately $50 \%$ recovery of activity. Partitioning of CP-1 between cellosolve, salt and urea resulted in low recovery of activity and the product was less potent than the starting material.

Further purification of $\mathrm{LH}$

When fraction CM-2 was chromatographed on DEAE-cellulose in 0.005 M-glycine buffer at $\mathrm{pH} 9.5$ virtually all of the $280 \mathrm{~m} \mu$-absorbing material was adsorbed by the ion-exchanger, and was eluted only at glycine concentration 
of $0.1 \mathrm{~m}$ and above. The remaining protein was eluted with $1 \mathrm{M}$-ammonium acetate. The fractions obtained, buffer concentration of eluant, yields and immunoassay data for $\mathbf{L H}$ are given in Table 3 . The best conditions for purification of the immunological LH activity in good yield are chromatography in $0.25 \mathrm{M}$-glycine buffer at $\mathrm{pH} 9 \cdot 5$. However, for one preparation (13-9-66) the DEAE-II fraction still contained as much LH as DEAE-I. Bio-assay of DEAE-I (19-1-66) by the OAAD method (Hartree, Butt \& Kirkham, 1964) was performed by Dr W. R. Butt who obtained a potency of 1380 i.u. HCG $/ \mathrm{mg}$ with $95 \%$ fiducial limits 670 to 3000 .

TABLE 4

WEIGHT YIELDS AND IMMUNOASSAYS OF HORSE LH PREPARATIONS PURIFIED BY CHROMATOGRAPHY ON IRC-50

\begin{tabular}{|c|c|c|c|}
\hline Fraction & Conditions for elution & $\begin{array}{l}\text { Yield }(\mathrm{g} / 100 \mathrm{~g} \text { of } \\
\text { pituitary powder })\end{array}$ & $\begin{array}{c}\text { Immunological estimate } \\
\text { of LH }(\% \text { of } \\
\text { human LH std })\end{array}$ \\
\hline $\begin{array}{l}\text { IRC-1 }(21-3-66) \\
\text { IRC-2 }(21-3-66)\end{array}$ & $\begin{array}{l}\text { pH } 8.0 \text { tris-phosphate, } 0.005 \mathrm{M} \text { in } \mathrm{Na}^{+} \\
1 \mathrm{M} \text {-ammonium acetate }\end{array}$ & $\begin{array}{l}0 \cdot 042 \\
0 \cdot 118\end{array}$ & $\begin{array}{l}1 \cdot 0 \\
3 \cdot 2\end{array}$ \\
\hline $\begin{array}{l}\text { IRC-1 }(28-6-66) \\
\text { IRC-2 }(28-6-66)\end{array}$ & $\begin{array}{l}\mathrm{pH} 8.2 \text { tris-phosphate, } 0.005 \mathrm{M} \text { in } \mathrm{Na}^{+} \\
1 \mathrm{M} \text {-ammonium acetate }\end{array}$ & $\begin{array}{l}0 \cdot 040 \\
0 \cdot 108\end{array}$ & $\begin{array}{l}0.53 \\
4 \cdot 3\end{array}$ \\
\hline
\end{tabular}

Rabbit antiserum to human $\mathbf{L H}$ was used in all immunoassays.

TABLE 5

WEIGHT YIELDS AND BIO-ASSAYS FOR HORSE GROWTH HORMONE PREPARATIONS

\begin{tabular}{l|c|c|c|c}
\hline \multicolumn{1}{c|}{ Preparation } & $\begin{array}{c}\text { Method } \\
\text { used }\end{array}$ & $\begin{array}{c}\text { Yield }(\mathrm{g} / 100 \mathrm{~g} \text { of } \\
\text { pituitary powder })\end{array}$ & $\begin{array}{c}\text { Growth hormone bio-assay } \\
\text { with fducial limits } \\
(\mathbf{P}=0.95)(\text { i.u. } / m g)\end{array}$ & $\begin{array}{c}\text { Index of } \\
\text { precision } \\
(\lambda)\end{array}$ \\
\hline $\begin{array}{c}\text { Horse GH E 198 G } \\
\text { from Batch A }\end{array}$ & 1 & 0.34 & $0.88 *(0.57$ to 1.34$)$ & 0.19 \\
$\begin{array}{c}\text { Horse GH (7-2-66) } \\
\text { from Batch 22 }\end{array}$ & 2 & 0.68 & $0.44(0.20$ to 0.91) & 0.32 \\
$\begin{array}{c}\text { Horse GH (22-3-66) } \\
\text { from Batch A } \\
\text { Crude horse GH (8-11-66) } \\
\text { from Batch 22 }\end{array}$ & 2 & 0.75 & $0.57(0.26$ to 1.16) & 0.32 \\
\hline
\end{tabular}

* Assayed at Emory University. The other preparations were assayed in Cambridge.

The methods used for preparation of horse GH are described in detail in the Materials and Methods section.

Further purification of fraction DEAE-I was attempted by chromatography on IRC-50. Columns of ion-exchanger $(1 \times 15 \mathrm{~cm})$ were equilibrated with trisphosphate buffer at $\mathrm{pH} 8$ containing $0.005 \mathrm{M}$-sodium ion, and $50 \mathrm{mg}$ of fraction DEAE-I (19-1-66) dissolved in the same buffer was applied and the column washed with additional buffer. After elution of the unadsorbed fraction, the protein remaining on the column was eluted with $1 \mathrm{M}$-ammonium acetate. The yields and immunoassay data from these experiments are given in Table 4. The fraction adsorbed by IRG-50 (IRG-2) appears to be somewhat more potent than the starting material. 


\section{Assay of $G H$ preparations and further purification}

Weight yields and bio-assay data on $\mathrm{GH}$ prepared by the three methods described in the Materials and Methods section are given in Table 5. The yield and potency of GH prepared by Raben's method (1959) is only slightly higher for recently collected glands than for acetone-dried glands stored for 25 years. Because of the imprecision of the bio-assays, this difference cannot be considered significant. The yield of $\mathrm{GH}$ prepared by Method 1 is only half as much as that prepared by Method 2, but the potency is appreciably higher. Method 3 yields a large amount of very low potency material.

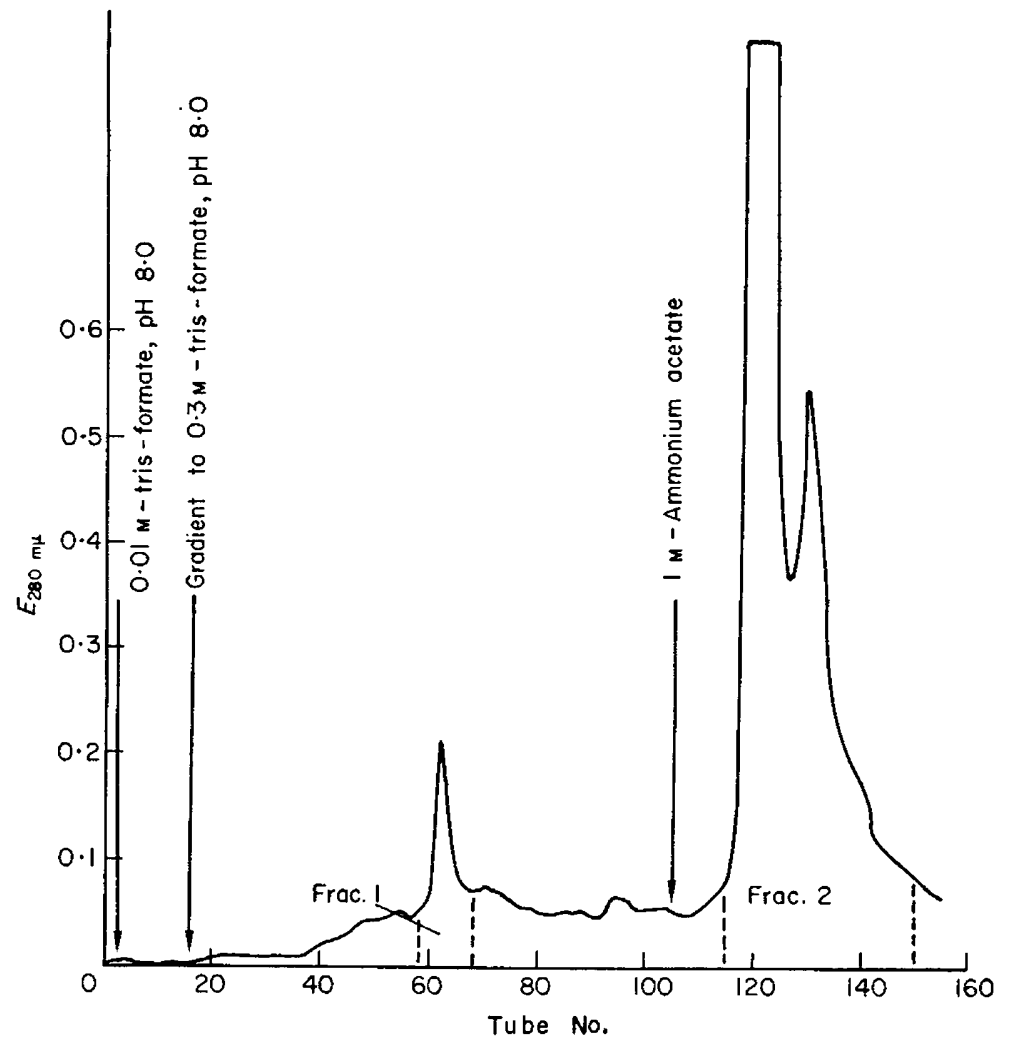

TEXT-FIG. 1. Chromatography of crude horse growth hormone on DEAE-cellulose. The column was equilibrated with $0.01 \mathrm{M}$-tris buffer (adjusted to $\mathrm{pH} 8.0$ with formic acid) and the protein was applied in the same buffer. At tube No. 16 gradient elution to $0 \cdot 3$ M-tris-formate at $\mathrm{pH} 8.0$ through a 500-ml mixing chamber was begun. At tube No. 105 $\mathrm{M}$-ammonium acetate was applied to the column. The tubes of effluent, containing $8.5 \mathrm{ml}$ each, were combined as fractions indicated by dotted lines.

Further purification of $\mathrm{GH}$ prepared by Method 3 was carried out using DEAE-cellulose chromatography. Gradient elution with tris-formate buffer at $\mathrm{pH} 8.0$ was employed since it had been effective in purification of pig and human growth hormones (Ashworth \& Wilhelmi, unpublished observations). Horse $\mathrm{GH}$ (352 mg; Method 3) was mixed with $35 \mathrm{ml}$ water and $2 \mathrm{~N}-\mathrm{NaOH}$ was added dropwise with stirring until it dissolved. It was then dialysed against $0.01 \mathrm{M}$-tris buffer (adjusted to $\mathrm{pH} 8.0$ with formic acid) and a large amount of 
insoluble material was removed by centrifugation. The soluble portion was applied to a column of DEAE-cellulose (Whatman DE-32, $2.1 \times 43.5 \mathrm{~cm}$ ) previously equilibrated with $0.01 \mathrm{M}$-tris-formate buffer at $\mathrm{pH} 8 \cdot 0$. Under these conditions all of the $280 \mathrm{~m} \mu$-absorbing material was adsorbed by the ion-exchanger. Gradient elution to $0.3 \mathrm{M}$-tris-formate at $\mathrm{pH} 8.0$ through a 500 $\mathrm{ml}$ mixing chamber resulted in elution of a small peak of $280 \mathrm{~m} \mu$-absorbing material (Text-fig. 1). Additional protein was eluted with I M-ammonium acetate. The tubes of effluent were pooled into Fractions 1 and 2 as shown in Text-fig. 1. Each fraction was adjusted to $\mathrm{pH} 5.5$ with glacial acetic acid and the protein precipitated at $4^{\circ} \mathrm{G}$ by dropwise addition of an equal volume of cold ethanol with stirring. After $48 \mathrm{hr}$ at $4^{\circ} \mathrm{G}$ (to complete precipitation) the protein was centrifuged at $4^{\circ} \mathrm{G}$, washed with ethanol and acetone and dried in vacuo.

TABLE 6

WEIGHT YIELDS AND BIO-ASSAYS OF HORSE GROWTH HORMONE PREPARATIONS AFTER DEAE-GELLULOSE GHROMATOGRAPHY

\begin{tabular}{|c|c|c|c|c|}
\hline Preparation & $\begin{array}{l}\text { Conditions for } \\
\text { elution }\end{array}$ & $\begin{array}{c}\text { Yield } \\
(\mathrm{g} / 100 \mathrm{~g} \text { of } \\
\text { pituitary } \\
\text { powder })\end{array}$ & $\begin{array}{c}\text { Growth hormone bio-assay } \\
\text { with fiducial limits } \\
(\mathrm{P}=0.95) \text { (i.u. } / \mathrm{mg})\end{array}$ & $\begin{array}{l}\text { Index of } \\
\text { precision } \\
\quad(\lambda)\end{array}$ \\
\hline DE-1 $(28-11-66)^{a}$ & $\begin{array}{l}\text { Gradient from } 0.01 \text { to } \\
0.3 \mathrm{M} \text {-tris formate, } \\
\text { pH } 8.0\end{array}$ & 0.43 & $0.56(0.24$ to 1.09$)$ & 0.27 \\
\hline $\begin{array}{l}\text { DE-2 }(28-11-66) \\
\text { DE-1 }(7-12-66)^{a}\end{array}$ & $\begin{array}{l}1 \mathrm{M} \text {-ammonium acetate } \\
0 \cdot 1 \mathrm{M} \text {-tris formate, } \mathrm{pH} \\
8 \cdot 0\end{array}$ & $\begin{array}{l}3 \cdot 2 \\
0 \cdot 71\end{array}$ & $\begin{array}{l}\text { Not assayed } \\
0.75(0.34 \text { to } 1.48)\end{array}$ & 0.27 \\
\hline $\begin{array}{l}\text { DE-2 }(7-12-66) \\
\text { DE-1 }(8-5-67)^{6}\end{array}$ & $\begin{array}{l}1 \mathrm{M} \text {-ammonium acetate } \\
0.035 \mathrm{M} \text {-tris formate, } \\
\mathrm{pH} 8.0\end{array}$ & $\begin{array}{l}2 \cdot 8 \\
0 \cdot 03\end{array}$ & $\begin{array}{l}0.03 \\
0.78(0.47 \text { to } 1.26)\end{array}$ & $0 \cdot 25$ \\
\hline DE-2 (8-5-67) & $1 \mathrm{M}$-ammonium acetate & 0.08 & $0.40(0.23$ to 0.68$)$ & $0 \cdot 25$ \\
\hline
\end{tabular}

a The starting material was crude horse GH (8-11-66) prepared by Method 3.

b The starting material was horse GH $(7-2-66)$ prepared by Method 2.

As a result of this experiment, a simpler procedure was developed in which the ion-exchanger was equilibrated with $0 \cdot 1$ M-tris-formate buffer and $\mathbf{G H}$ (Method 3) was equilibrated with the same buffer and applied to the column. The column was washed with additional buffer and the unadsorbed material was pooled as fraction DE-1. Additional protein (fraction DE-2) was eluted with I M-ammonium acetate. Data on yields and potencies of these preparations are given in Table 6 .

Further purification of horse GH (Method 2) was performed by DEAEcellulose chromatography at $\mathrm{pH} 8.0$ and stepwise changes in buffer concentration. The yields and potencies of these fractions are also given in Table 6.

Dr Isabel Forsyth has assayed two preparations for prolactin activity by local injection into the pigeon crop gland. Raben horse GH (7-2-66) contained 0.1 to 0.5 i.u. prolactin $/ \mathrm{mg}$ and preparation DE-1 (7-12-66) contained less than $0 \cdot 1$ i.u. prolactin $/ \mathrm{mg}$.

The method which gives the best yield of high potency GH (DE-1, 7-12-66) 
with negligible contamination with prolactin is thus alkaline extraction (Method 3) followed by chromatography on DEAE-cellulose in $0 \cdot 1 \mathrm{M}$-trisformate at $\mathrm{pH} 8 \cdot 0$.

\section{Immunological studies of growth hormones}

Antiserum to pig GH was effective in agglutinating sheep red blood cells coated with horse $\mathrm{GH}$ or with pig Gr. In addition to this demonstration of immunological cross-reaction, pig, horse, beef and human growth hormones were tested for inhibition of haemagglutination in both systems and also with human GH antiserum and erythrocytes coated with the same hormone. The

TABLE 7

IMMUNOLOGICAL COMPARISON OF GROWTH HORMONES FROM DIFFERENT SPECIES

\begin{tabular}{|c|c|c|c|}
\hline Antiserum: & \multicolumn{2}{|c|}{$\begin{array}{c}\text { Antiserum to pig } G H(\mathrm{P} 511 \mathrm{~A}) \text { raised in } \\
\text { guinea-pigs diluted } 1: 9600\end{array}$} & $\begin{array}{c}\text { Antiserum to human } G H(M Y-61) \text { raised } \\
\text { in rabbits diluted } 1: 2400\end{array}$ \\
\hline $\begin{array}{l}\text { Antigen attached } \\
\text { to cells: }\end{array}$ & $\begin{array}{l}\text { Pig GH } \\
(\text { P } 511 \mathrm{~A})\end{array}$ & $\begin{array}{l}\text { Horse GH (DEAE- } \\
\quad 1,25-7-66)\end{array}$ & Human GH (MY-61) \\
\hline Antigen & \multicolumn{3}{|c|}{ Dilution of antigen $(\mathrm{mg} / \mathrm{ml})$ at which haemagglutination was inhibited } \\
\hline $\begin{array}{l}\text { Pig GH (P 511 A) } \\
\text { Horse GH (E 198 C) } \\
\text { Beef GH (B 809 A) } \\
\text { Human GH (MY-61) }\end{array}$ & $\begin{array}{l}1: 5540 \\
1: 980 \\
1:>2560 \\
\text { Not tested }\end{array}$ & $\begin{array}{l}1: 695 \\
1: 2770 \\
1: 2770 \\
1:<5\end{array}$ & $\begin{array}{l}<2 \\
1: 1 \cdot 5 \\
<2 \\
1: 9600\end{array}$ \\
\hline
\end{tabular}

results are given in Table 7. High dilutions of pig, beef and horse growth hormones were effective in neutralizing antiserum to pig $\mathbf{G H}$, thus inhibiting agglutination of cells coated with pig or horse $\mathrm{GH}$, but human $\mathrm{GH}$ was ineffective. Conversely, pig and beef hormones did not prevent haemagglutination of cells coated with the human hormone in the presence of antiserum to human $\mathrm{GH}$. Horse GH showed a slight cross-reactivity with human GH. At low dilution it neutralized antiserum to human $\mathrm{GH}$ and prevented haemagglutination.

\section{DISGUSSION}

Saxena, McShan \& Meyer (1962) have described purification of horse FsH and Saxena \& Henneman $(1965,1966)$ have given methods for separation and purification of horse FSH, LH and GH. A comparison of the potency of the purified FSH of Saxena et al. (1962) with our CP-1 can be made if we use the values determined by Butt, Crooke \& Wolf (1965) for converting standard NiH-FSH into i.u. 2nd IRP-HGM (8 i.u. 2nd IRP-HGM $=0.31 \mathrm{mg}$ NIH-FSH-sl). Their preparation would thus be 181 i.u. 2nd IRP-HGM/mg, which is in the potency range of our GP-1 preparations. Assuming that horse pituitary glands contain $80 \%$ water, our average yield of CP-1 $(0 \cdot 14 \mathrm{~g} / 100 \mathrm{~g}$ pituitary powder $=280$ $\mu \mathrm{g} / \mathrm{g}$ fresh glands) is about four times higher than theirs ( $59 \mu \mathrm{g} / \mathrm{g}$ fresh glands). Standard hormone preparations were not included in the assays of Saxena \& Henneman (1965) for FSH and LH activities and so the yields and potencies of 
our gonadotrophin fractions cannot be compared with theirs. Reichert \& Wilhelmi (1965) have purified horse LH by ethanol and trichloroacetic acid fractionation followed by chromatography on DEAE-cellulose and IRG-50. This method yielded $367 \mathrm{mg} \mathrm{LH} / \mathrm{kg}$ of whole glands of potency $0.9 \times$ standard NIH-LH-sl. Our DEAE-I (19-1-66), which was bio-assayed in terms of an HCG standard, is of approximately the same potency if we use the conversion factor reported by Butt et al. (1965), i.e. that $0.0053 \mathrm{mg}$ NIH-LH-sl is equivalent to 10 i.u. HGG. Thus the assay value of $1380 \mathrm{i}$.u. $\mathrm{HGG} / \mathrm{mg}$ is equivalent to $0.73 \times$ standard NIH-LH-sl. Again assuming an $80 \%$ water content of the glands, our yield of $\mathrm{LH}(0.21 \mathrm{~g} / 100 \mathrm{~g}$ pituitary powder $=420 \mathrm{mg} / \mathrm{kg}$ whole gland) is also comparable to theirs. Although we used different conditions of $\mathrm{pH}$ and ionic strength for DEAE-cellulose chromatography, our IRC-50 purification was performed with a similar buffer system and our finding that LH was adsorbed to the ion-exchanger under these conditions is in complete agreement with theirs.

The yield of GH obtained by Saxena \& Henneman (1966) from the pituitary residue after extraction of gonadotrophin was about twice as high as ours although we followed the same method (Raben, 1959). After further purification by gel-filtration, their material was as potent as our most active preparation ( 0.9 i.u./mg). Although their purified GH still contained significant prolactin, our preparation which had been chromatographed on DEAE-cellulose was devoid of this activity.

Our procedure is the first elaboration of a method for obtaining horse pituitary $\mathbf{~ F S H , ~} \mathbf{L H}$ and $\mathrm{GH}$ from the same starting material with known yields of activity. It is of interest that the yields of $\mathrm{FSH}, \mathrm{LH}$ and $\mathrm{GH}$ from acetone-dried pituitaries stored for 25 years are similar to those obtained from glands stored for only a few months.

The initial extraction of horse FsH and $\mathbf{L H}$ followed by their separation on a CM-cellulose column has been achieved by the methods used for the corresponding human hormones. Further purification of horse FsH by calcium phosphate adsorption and DEAE-cellulose chromatography, as applied to human FSH (Butt et al., 1961a), was also effective. The average recovery of activity in horse CP-1 is 26,300 i.u./100 g of pituitary powder which represents $41 \%$ of the FSH originally present $(64,000$ i.u. $/ 100 \mathrm{~g}$ of pituitary powder). Further purification of horse CP-1 by partitioning between cellosolve, salt and urea was unsuccessful and resulted in $90 \%$ loss of activity. Thus horse FSH is not as stable to this treatment as human FsH.

Chromatography of horse GM-2 ( $\mathrm{LH})$ on DEAE-cellulose at $\mathrm{pH} 9.5$ in glycine buffer required higher ionic strength ( $0.25 \mathrm{M}$-glycine) than was necessary for human LH $(0.1 \mathrm{M}$-glycine) in order to recover most of the activity in the unadsorbed fraction. This suggests that horse $\mathbf{L H}$ is slightly more acidic than human LH.

The Raben method (1959) is effective for purification of both horse and human growth hormones. Horse $\mathrm{GH}$ is obtained in lower yield $(0.7 \mathrm{~g} / 100 \mathrm{~g}$ of pituitary powder) than is human $\mathrm{GH}(4.3 \mathrm{~g} / 100 \mathrm{~g})$ (Hartree, 1966), but Saxena \& Henneman (1966) report higher yields of horse $\mathrm{GH}(1.5 \mathrm{~g} / 100 \mathrm{~g})$ by this method. 
The biological potencies of horse CP-1 (FSH), DEAE-1 (LH) and Raben GH are all somewhat lower than the corresponding human preparations. Although it is possible that they are less highly purified, the horse hormones may be less active in the assay animals (rats and mice) than are the human hormones because of differences in response among species.

The immunological estimates of horse $\mathrm{LH}$ activities in various fractions cannot be directly compared with the corresponding human preparations because only a relatively weak cross-reaction between horse LH and antiserum to human LH is measured. The horse preparations have immunological potencies 7 to $10 \%$ of the corresponding human fractions in our assay system.

Although we have not shown correlation between biological assay and our immunoassay for horse $\mathrm{LH}$, it is known that this immunoassay for human $\mathrm{LH}$ correlates well with bio-assay by the OAAD method (Hartree et al., 1964). Moreover, comparison of bio-assay of sheep pituitary fractions with immunoassay (Hartree \& Greenhalgh, unpublished results) suggests that in this species the two methods agree within their limits of precision. In the present study, horse LH activity was followed solely by immunoassay. Bio-assay of a purified fraction (DEAE-1, 19-1-66) demonstrated that its yield and potency were comparable to horse LH prepared by a very different method (Reichert \& Wilhelmi, 1965). The use of an immunological cross-reaction between HCG (attached to sheep erythrocytes) and antiserum to human LH decreases the possibility that pituitary protein contaminants of human or horse $\mathbf{L H}$ will be measured in the immunoassay. Since chorionic gonadotrophin is obtained from pregnancy urine it is unlikely to possess the same contaminants present in pituitary LH fractions.

In our immunological studies of horse $\mathrm{GH}$ by the method of haemagglutination inhibition, we observed strong cross-reactions between horse, pig and beef growth hormones and a very weak cross-reaction between horse and human hormones. Saxena \& Henneman (1966) reported no cross-reaction between horse and human $\mathrm{GH}$ in a system similar to ours, and Laron (quoted by Saxena \& Henneman, 1966) was unable to demonstrate cross-reaction between horse GH and antiserum to beef $\mathrm{GH}$ in an Ouchterlony double diffusion system. These differences in immunological results may be explained by differences in the antisera or in the immunological methods employed.

\section{ACKNOWLEDGMENTS}

We are indebted to Professor A. S. Parkes for a gift of horse pituitary powder, to Dr W. D. Butt for advice on purification of FsH and for bio-assay of an LH preparation, and to Dr Isabel Forsyth for prolactin assays. The technical assistance of G. Brighouse, Mrs B. Brown and Mrs W. Thorn is gratefully acknowledged. We thank Professor F. G. Young for his encouragement. This work was supported by a grant from the Medical Research Council (to A.S.H.), a postdoctoral fellowship from the U.S. National Science Foundation (to J.B.M.) and a grant from the New Zealand Department of Agriculture (to R.A.S.W.). 


\section{REFERENCES}

Brown, P. S. (1955) The assay of gonadotrophin from urine of non-pregnant human subjects. F. Endocr. $13,59$.

BRown, P. S. \& Welds, M. (1966) Observations on the assay of human urinary follicle-stimulating hormone by the augmentation test in mice. 7. Endocr. 35, 199.

Butt, W. R., Crooke, A. C. \& Cunningham, F. J. (1961a) Studies on human urinary and pituitary gonadotrophins. Biochem. 7. 81, 596.

Butt, W. R., Crooke, A. C., Cunningham, F. J. \& Evans, A. J. (1961b) Chemical reactions which affect the biological activity of human gonadotrophins. Biochem. 7. 79, 64 .

Butt, W. R., Grooke, A. G. \& Wolf, A. (1965) Some problems related to the investigation of the immunological properties of human pituitary follicle-stimulating hormone. Ciba Fdn Study Grps., No. 22, p. 85.

Chance, M. R. A., Rowlands, I. W. \& Young, F. G. (1939) Species variation in thyrotrophic, gonadotrophic, and prolactin activities of the anterior hypophyseal tissue. F. Endocr. 1, 239.

Chen, H. (1964) Pituitary growth hormone. Ph.D. thesis, Emory University.

EhrLICH, R. M. \& RANDLE, P. J. (1961) Immunoassay of growth hormone in human serum. Lancet, ii, 230.

Hartree, A. S. (1966) Separation and partial purification of the protein hormones from human pituitary glands. Biochem. F. 100, 754 .

Hartree, A. S., Butt, W. R. \& Kirkham, K. E. (1964) The separation and purification of human luteinizing and thyrotrophic hormones. $\mathcal{F}$. Endocr. 29, 61 .

Hartree, A. S., Kovačrć, N. \& Thomas, M. (1965) Growth-promoting and luteotrophic activities of human growth hormone. F. Endocr. 33, 249.

Hememan, M. L., Bakke, J. L. \& Lawrence, N. L. (1959) Cation exchange chromatography of human pituitary thyrotropic activity. Archs Biochem. Biophys. 82, 62.

Main, R. K., Wilkins, M. J. \& Cole, L. J. (1959) A modified calcium phosphate for column chromatography of polynucleotides and proteins. F. Am. chem. Soc. 81, 6490 .

Raben, M. S. (1959) Human growth hormone. Recent Prog. Horm. Res. 15, 71.

READ, C. H. \& BRYAN, G. T. (1960) Immunological studies of human growth hormone. Ciba Fdn Colloq. Endocr. 13, 68.

Reichert, L. E., JR \& Wilhelmi, A. E. (1965) Preparation of equine luteinizing hormone. Endocrinology, $76,762$.

Saxena, B. B. \& HeNneman, P. H. (1965) An improved method for preparation of follicle stimulating and luteinizing hormones from horse pituitary glands. Biochim. biophys. Acta, 104, 496.

Saxena, B. B. \& Henneman, P. H. (1966) Preparation and properties of growth hormone from equine pituitary glands. Endocrinology, 78, 561.

Saxena, B. B., McShan, W. H. \& Meyer, R. K. (1962) Purification of follicle-stimulating hormone from horse anterior pituitary glands. Biochim. biophys. Acta, 65, 394 . 